\title{
液体の滑落性に着目した撥液処理の開発動向
}

\author{
穂積篤 ${ }^{\mathrm{a}}$, 佐藤 知哉 ${ }^{\mathrm{a}}$, Liming Wang ${ }^{\mathrm{a}}$, 浦田 千尋 ${ }^{\mathrm{a}}$, Matt W. England ${ }^{\mathrm{a}}$ \\ ${ }^{a}$ (国研) 産業技術総合研究所 構造材料研究部門 ( ⿳ 463-8560 愛知県名古屋市守山区下志段味穴ヶ洞 2266-98)
}

\section{Current Research Trends in Liquid-Repellent Treatments Focused on the Improvement of Sliding Properties}

\author{
Atsushi HOZUMI a, Tomoya SATO ${ }^{\text {a }}$, Liming WANG ${ }^{\text {a }}$, Chihiro URATA ${ }^{\text {a }}$ and Matt W. ENGLAND ${ }^{\text {a }}$
}

${ }^{a}$ Structural Materials Research Institute, National Institute of Advanced Industrial Science and Technology (AIST) (2266-98, Anagahora, Shimoshidami, Moriyama-ku, Nagoya-shi, Aichi 463-8560)

Keywords : Liquid-Repellent, Dynamic Contact Angle, Tilt/Sliding Angle, Contact Angle Hysteresis, Biomimetics

\section{1.はじめに}

生物は数億年にわたる進化の過程において, その表面構造 を最適化することにより, 過酷な自然環境, 生存競争を生き 抜くために必要不可欠な特異機能を獲得してきた。例えば, 蓮の葉の超撥水性・セルフクリーニング機能 ${ }^{1)}$, アメンボの 水面を歩く能力 ${ }^{2)}$, 砂漠に生息するゴミムシダマシの水収集

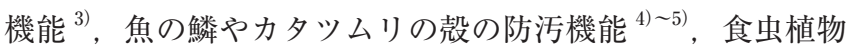
内壁の高滑落性 ${ }^{6}$, , トビムシ体表の耐圧性撥液機能 ${ }^{7)}$ などが 挙げられる。これらの優れた表面機能の発現には, 表面に存 在する数百 $\mathrm{nm}$ 数 $\mu \mathrm{m}$ の「サブセルラー・サイズ」の特異 な階層構造と素材固有の表面エネルギーに由来する濡れ性が 重要な役割を果たしている。生物は生息する環境に最も適し た微細構造を, 地球上にふんだんに存在する安価なユビキタ ス (汎用)元素 (炭素, 水素, 酸素, ケイ素, 窒素等)を使い, 常温・常圧という極めて温和な条件下, 自己組織化プロセス により造り上げている。希少元素, 有機フッ素化合物, 化石 燃料, トップダウンプロセスに依存する我々人類のものづく りの手法とはパラダイムが全く異なる。我が国では, 1990 年代から蓮の葉を模倣した超撥水性に関する研究が盛んに行 われてきた。21 世紀に入り,世界的なバイオミメティクス (生 物模倣技術) ブームの追い風を受け，超撥水性に関連する論 文は 2004 年頃から急激に増加し, その累計は既に一万報を 超えている (Web of Science ${ }^{\mathrm{TM}} に て$, topic = superhydrophobic* で検索)。また, 当該研究は材料科学における先端研究領域 トップ二十項目の中で七番目にランキングされている ${ }^{8)}$ 。最 近では, 水だけでなく, 油や有機溶剤のような表面張力の低 い液体, マヨネーズのような粘性の高いエマルションに対し て超撥液性(本稿では, 様々な液体をはじく性質を撥液性と 表記するとともに, 学術的な定義ではないが接触角が $150^{\circ}$ 以上の場合に“超”をつけることにする）を示す表面 (superomniphobic/amphiphobic surfaces) ${ }^{9) \sim 31)}$ の開発が世界中 で進められており，この分野は活況を呈している。

本稿では, 撥液処理の最新の研究開発動向を概説しながら,
優れた滑落性を付与することを可能にする撥液処理の概念と 著者らのこれまでの具体的な開発事例について述べる。

\section{2. 静的 /動的濡れ性}

固体表面が液体をはじきやすいか, あるいは液体に濡れや すいかという判断は, 一般的に, 液滴の接線と固体表面との なす角度, すなわち, 接触角 (ほとんど静止した状態での接 触角という意味で静的接触角 (以下, $\theta_{\mathrm{S}}$ と示す), あるいは 見かけの接触角ともいう)を用いて判断する。水をプローブ に使用した場合は水滴接触角という。接触角は固体表面の最 外層のみの物性を反映しており， $\theta_{\mathrm{S}}$ が大きい $\left(>90^{\circ}\right)$ 表面ほ ど撥液性が高く(濡れにくい), 小さい $\left(<90^{\circ}\right)$ 表面ほど撥液 性が低い(濡れやすい)と認識されている。

図 1 に熱 CVDにより作製した有機シラン重合膜 ${ }^{32)}$ 上の水 滴の状態を示す。パネル $(\mathrm{a})$ と $(\mathrm{b})$ はいずれも水滴の $\theta_{\mathrm{S}}$ が $160^{\circ}$ 以上の超撥水表面で, 両者の濡れ性の違いはこの写真か

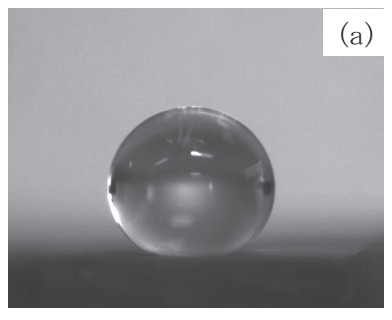

傾斜: $5^{\circ}<$

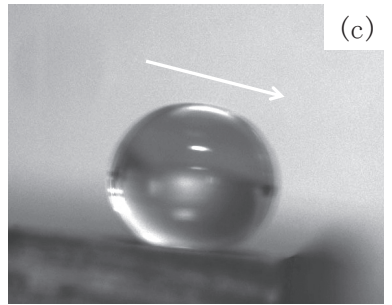

(c)

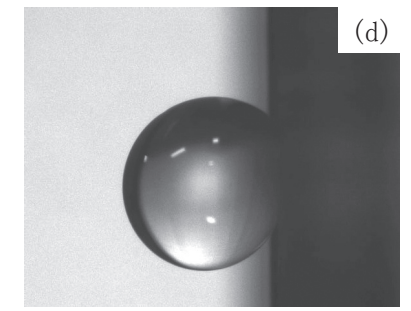

図 1 基板を傾けた際の水滴の動的挙動の違い：(a),(b) 表面ともに $\theta_{\mathrm{s}}$ は約 $160^{\circ}$

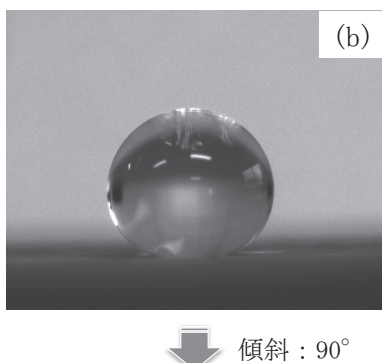

d) 
らでは判断できない。しかし，基板を傾けた場合の水滴の挙 動を比較してみると違いは明らかである。(a)の表面では基 板をわずか数度傾けただけで水滴は容易に転がり落ちるのに 対し(パネル (c))，（b)の表面は基板を $90^{\circ}$ 傾けても水滴はピ ン止めされたまま残っている(パネル $(\mathrm{d}))$ 。実は (b)の表面に は水滴の接触面 (3 相接触線の内側) に小さな親水性のスポッ トが存在し，そこに水滴がピン止めされている。このような 簡単な実験からも明らかなように, 水滴の “静的” な状態 $\left(\theta_{\mathrm{S}}\right)$ だけでは固体表面の真の濡れ性を評価することが困難である ことは容易に想像できる。

このような背景から, 最近, 固体表面からの液滴除去性能 の指標として, “動的” な濡れ性評価 (動的接触角, 接触角七 ステリシス, 転落角)の重要性が認識されつつある。動的接 触角とは固体表面上を液滴が動く状態を想定した, 液滴の前 進 $\left(\theta_{\mathrm{A}}\right)$ ・後退 $\left(\theta_{\mathrm{A}}\right)$ 接触角によって決定される值である。 $\theta_{\mathrm{A}}$ と $\theta_{\mathrm{R}}$ の差 $\left(\Delta \theta=\theta_{\mathrm{A}}-\theta_{\mathrm{R}}\right)$ あるいは $\theta_{\mathrm{A}}$ と $\theta_{\mathrm{R}}$ の余弦の差 $\left(\Delta \theta_{\cos }=\right.$ $\left.\cos \theta_{\mathrm{R}}-\cos \theta_{\mathrm{A}}\right)$ は接触角ヒステリシスとして定義される。接 触角ヒステリシスの原因は, 表面の粗さ, 化学的不均一性, 固液界面での分子再配列等の影響によるものといわれている ${ }^{33)}$ フッ素系シランカップリング剂で処理した自動車用撥水ガラ スで問題となっている雨滴残り (低雨滴飛散性)による視界低 下や污れの付着はこの接触角ヒステリシスが原因であるとい われている ${ }^{34)}$ 。

Kawasaki や Furmidge ${ }^{35) \sim 36)}$ は, 動的接触角 (接触角ヒステ リシス) と液滴が動き出す際の基板の傾斜角との間には式 (1) のような関係が成り立つと報告している。

$$
F_{\mathrm{S}}=m g(\sin \alpha)=k w \gamma_{\mathrm{LV}}\left(\cos \theta_{\mathrm{R}}-\cos \theta_{\mathrm{A}}\right)
$$

$\alpha$ : 基板の傾斜角, $k$ : 定数, $\mathrm{w}$ : 液滴の幅,

$\gamma_{\mathrm{LV}}:$ 液滴の表面張力

この式からも明らかなように，接触角ヒステリシスが小さ ければ，わずかな傾斜で液滴が滑落すると推測できる(本稿
では，液滴が滑落する際の基板の傾斜角を転落角 $\left(\theta_{\mathrm{T}}\right)$ と表記 する)。我々は最近, 接触角ヒステリシス $\left(\Delta \theta\right.$ と $\left.\Delta \theta_{\mathrm{cos}}\right)$ が液滴 の滑落性に及ぼす影響を調べ，後者 $\left(\Delta \theta_{\text {cos }}\right)$ と相関関係がある ことを確認している ${ }^{37)}$ 。 $\theta_{\mathrm{T}}$ は液滴量(重力)に依存するため, 滑落性を比較する場合, 液滴量を必ず一定にして測定する必 要がある。また, 液滴が動き始めたかどうかの判断も慎重に 行う必要がある。前述のように，これまでの超撥水性，超撥 液性の定義は， $\theta_{\mathrm{S}}$ が $150^{\circ}$ 以上の表面とされてきた。しかし， 図 1 に示したように $\theta_{\mathrm{S}}$ だけでは真の濡れ性を評価すること が困難であることが認識され始め, 最近の定義は, 静的接触 角 $\left(\theta_{\mathrm{S}} \geqq 150^{\circ}\right)$ に加え, 接触角ヒステリシス $\left(\Delta \theta \leqq 5-10^{\circ}\right)$ や転落角 $\left(\theta_{\mathrm{T}} \leqq 5-10^{\circ}\right.$, ただし液滴量は不明)の值も考慮し, 総合的に評価されるようになってきた(いずれも学術的な定 義ではない) ${ }^{38)}$ 。また，測定に用いるプローブ液体の表面張 力 $\left(\gamma_{\mathrm{LV}}\right)$ によって固体表面の撥液性能に違いが生じることは 言うまでもない。一口に油といってもその種類は様々で, 例 えば, $n$-ヘプタン $\left(\gamma_{\mathrm{LV}}=20.1 \mathrm{dyn} / \mathrm{cm}\right)$ とジクロロメタン $\left(\gamma_{\mathrm{LV}}\right.$ $=50.8 \mathrm{dyn} / \mathrm{cm})$ では $30 \mathrm{dyn} / \mathrm{cm}$ 以上の差がある。そのため, サンプル間の撥液性能の比較を容易にするために，測定には $\gamma_{\mathrm{LV}}$ が十分に低い $30 \mathrm{dyn} / \mathrm{cm}$ 以下の液体, 例えば, $n^{-}$ヘキサ デカン $(27.3 \mathrm{dyn} / \mathrm{cm})$, をプローブ液体として用いるべきとの 指摘もある ${ }^{23)}$ 。

\section{3. 最近の撥液処理の研究動向}

最近の撥液処理は, 1) 従来の蓮の葉を模倣した超撥水処理と 同じく，表面の微細構造化と低表面エネルギー化により $\theta_{\mathrm{S}}$ を極 限まで大きくしてプローブ液体と固体表面の接触面積を小さく する手法(表 1, 以下, 超撥液処理と示す) ${ }^{9)}$-31)，2) プローブ液 体と液体表面(表 2) ${ }^{39) \sim 47)}$ あるいは固体表面(表 3) ${ }^{32), 37), 48) ~ 62) ~}$ の相互作用を小さくし，プローブ液体の滑落性を向上させる 手法, の 2 つに大別することができる。表 1 からも明らか

表 1 代表的な超撥液表面の作製方法とその動的濡れ性：()内の数字はプローブ液体の種類

\begin{tabular}{|c|c|c|c|c|c|c|c|}
\hline 基板 or 素材 & $\begin{array}{l}\text { 微細構造化 } \\
\text { プロセス }\end{array}$ & $\begin{array}{c}\text { 低表面エネルギー化 } \\
\text { 処理 }\end{array}$ & $\begin{array}{l}\text { プローブ } \\
\text { 液体(抜粋)* }\end{array}$ & $\begin{array}{c}\theta_{\mathrm{s}}\left(^{\circ}\right) \\
\text { or } \\
\theta_{\mathrm{A}} / \theta_{\mathrm{R}}\left({ }^{\circ} /{ }^{\circ}\right) \\
\end{array}$ & $\begin{array}{l}\Delta \theta \\
\left({ }^{\circ}\right)\end{array}$ & $\begin{array}{l}\theta_{\mathrm{T}} \\
\left({ }^{\circ}\right)\end{array}$ & 文献 \\
\hline $\mathrm{Ti}$ & 陽極酸化 & $\mathrm{CF}_{3}\left(\mathrm{CF}_{2}\right)_{5} \mathrm{CH}_{2} \mathrm{CH}_{2} \mathrm{SiCl}_{3}$ & $1,2,3,5,6,7,8,9$ & $152-167$ & - & $<2-9$ & 14 \\
\hline $\mathrm{SiO}_{2}$ & ナノファイバー & $\mathrm{CF}_{3}\left(\mathrm{CF}_{2}\right)_{7} \mathrm{CH}_{2} \mathrm{CH}_{2} \mathrm{SiCl}_{3}$ & $\begin{array}{l}1,6,9,10,11 \\
12,13,14,15\end{array}$ & $156.6-174.4$ & - & $1.2-5.7$ & 15 \\
\hline $\mathrm{Al}$ & $\begin{array}{l}\text { 化学エッチング + } \\
\text { 熱水処理 }\end{array}$ & $\mathrm{CF}_{3}\left(\mathrm{CF}_{2}\right)_{6} \mathrm{COOH}$ & $1,3,4,8,9,10,11$ & $151.5-164.4$ & $\begin{array}{c}(1,3,4,8,9) \\
2.3-8.0 \\
(10) 18.1 \\
(11) 45.1\end{array}$ & $\begin{array}{c}(1,3,4,8,9) \\
3.2-7.2 \\
(10) 14.9 \\
(11) 40.1\end{array}$ & 18 \\
\hline $\mathrm{SiO}_{2}$ & ロウソクの煤 & $\mathrm{CF}_{3}\left(\mathrm{CF}_{2}\right)_{5} \mathrm{CH}_{2} \mathrm{CH}_{2} \mathrm{SiCl}_{3}$ & $1,4,6,9,16,17,18$ & $154-165$ & $2-6$ & $1-5$ & 19 \\
\hline $\begin{array}{l}\text { スチール } \\
\text { メッシュ }\end{array}$ & $\begin{array}{l}\text { エレクトロスピニ } \\
\text { ング }\end{array}$ & $\begin{array}{l}\text { Perfluorodecyl-POSS } \\
\left(\left(\mathrm{CF}_{3}\left(\mathrm{CF}_{2}\right)_{7} \mathrm{C}_{2} \mathrm{H}_{4} \mathrm{SiO}_{1.5}\right)_{8}\right)+ \\
\text { PDMS }\end{array}$ & $\begin{array}{l}1,3,4,6,9,12,19,20, \\
21,22,23,24,25\end{array}$ & - & $2-7$ & $0.5-2$ & 20 \\
\hline ガラス & $\begin{array}{l}\text { リアクテイブイオ } \\
\text { ンエッチング+燃 } \\
\text { 焼 CVD } \\
\end{array}$ & フルオロシラン & $1,9,27$ & $153-172$ & - & $<3-<6$ & 25 \\
\hline $\mathrm{SiO}_{2}$ & $\begin{array}{l}\text { リアクティブイオ } \\
\text { ンエッチング }\end{array}$ & なし & $12,21,24,28,29,30$ & $\begin{array}{l}\text { (12) } 156.0 / 134.9 \\
\text { (21) } 157.6 / 137.3 \\
\text { (24) } 157.1 / 136.1 \\
\text { (29) } 157.4 / 136.2 \\
\text { (30) } 153.8 / 136.1 \\
\end{array}$ & $20.3-21.7$ & $<6$ & 27 \\
\hline
\end{tabular}

*1: 水， $2:$ 塩水， $3:$ グリセロール，4: エチレングリコール， $5:$ 流動パラフィン， $6:$ ヨウ化メチレン, $7:$ 原油 $, 8:$ 菜種油, $9: n$-ヘキサデカン, $10: n$-ドデカン $11: n^{-}$デカン, 12 : トルエン, $13:$ 鉱油, $14: p$-キシレン, $15:$ シクロヘキサン, $16:$ ピーナッツ油, $17:$ オリーブ油, $18: n$-テトラデカン, $19:$ 酢酸,

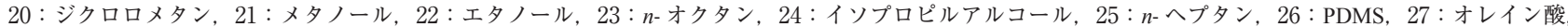
28 : アセトン, $29: n$-ヘキサン, $30: \mathrm{C}_{6} \mathrm{~F}_{14}$, 
表 2 代表的な液体膜の作製手法とその動的濡れ性：()内の数字はプローブ液体の種類

\begin{tabular}{|c|c|c|c|c|c|c|c|}
\hline 素材 & $\begin{array}{l}\text { 微細構造化 } \\
\text { プロセス }\end{array}$ & 低表面エネルギー化処理 & プローブ液体 * & $\theta_{\mathrm{A}} / \theta_{\mathrm{R}}\left({ }^{\circ} /^{\circ}\right)$ & $\Delta \theta\left(^{\circ}\right)$ & $\theta_{\mathrm{T}}\left({ }^{\circ}\right)$ & 文献 \\
\hline $\begin{array}{l}\text { ·エポキシ樹脂製 } \\
\text { ナノポストアレイ } \\
\text { ・テフロン製多孔質 } \\
\text { ナノファイバー網 }\end{array}$ & $\begin{array}{l}\text { ソフト } \\
\text { リソグラフィー }\end{array}$ & $\begin{array}{l}\text { パーフルオロアルキルシラン / } \\
\text { パーフルオロポリエーテル or } \\
\text { パーフルオロトリ }-\mathrm{n}-\text { ペンチルアミン }\end{array}$ & $\begin{array}{l}\text { 1, 炭化水素系液体, } \\
\text { 原油, 血液, ジャム }\end{array}$ & - & $<2.5$ & 5 & 39 \\
\hline アルミナゲル & 熱水処理 & $\begin{array}{l}\text { パーフルオロホスホン酸/ } \\
\text { パーフルオロポリエーテル }\end{array}$ & $1,2,3,4,5$ & $\begin{array}{l}\text { (1) } 121 / 119 \\
\text { (2) } 71.8 / 69.3 \\
\text { (3) } 65.7 / 62.5 \\
\text { (4) } 66.2 / 60.2 \\
\text { (5) } 70.5 / 66.4 \\
\end{array}$ & $2-6$ & $<5$ & 40 \\
\hline $\begin{array}{l}\mathrm{SiO}_{2} \text { ナノ粒子 }+ \\
\text { キチンナノファイバー }\end{array}$ & 交互積層法 & $\begin{array}{l}\text { パーフルオロアルキルシラン / } \\
\text { パーフルオロポリエーテル }\end{array}$ & $1,2,6,7$ & - & - & $2-10$ & 41 \\
\hline $\mathrm{SiO}_{2}$ 粒子 & 熱 CVD & $\begin{array}{l}\text { アミノシラン/ } \\
\text { フッ素系イオン液体 }\end{array}$ & $1,2,8,9,10,11,12$ & $\begin{array}{l}\text { (1) } 50.6 / 49.3 \\
\text { (2) } 33.7 / 32.0 \\
\text { (8) } 52.6 / 50.1 \\
\text { (9) } 28.7 / 26.5 \\
\text { (10) } 29.3 / 28.2 \\
\text { (11) } 24.8 / 23.2 \\
\text { (12) } 18.6 / 17.1 \\
\end{array}$ & $1.1-2.5$ & $\begin{array}{l}\text { (1) } 3.0 \\
\text { (2) } 2.0 \\
\text { (8) } 2.3 \\
\text { (9) } 1.3 \\
\text { (10) } 2.3 \\
\text { (11) } 3.8 \\
\text { (12) } 3.7 \\
\end{array}$ & 43 \\
\hline $\begin{array}{l}\mathrm{SiO}_{2} \text { ナノ粒子 + フッ素系 } \\
\text { メタクリル酸共重合体 }\end{array}$ & はけ塗り & パーフルオロポリエーテル & $1,13,14$ & - & $<5$ & $4-6$ & 44 \\
\hline
\end{tabular}

* $1:$ 水, $2: n$-ヘキサデカン, $3:$ アセトン, $4:$ THF, $5:$ トルエン, $6: n$-オクタン, $7:$ 菜種油, $8: \exists ウ$ タ化メチレン, $9:$ ヨードベンゼン

$10: n$-テトラデカン, $11: n$-ドデカン, $12: n$-デカン, $13:$ オーブオイル, $14:$ エタール

表 3 代表的な Liquid-like 膜の作製手法とその特性：()内の数字はプローブ液体の種類

\begin{tabular}{|c|c|c|c|c|c|c|}
\hline 基板 & 低表面エネルギー化処理 & $\begin{array}{l}\text { プローブ } \\
\text { 液体* }\end{array}$ & $\theta_{\mathrm{A}} / \theta_{\mathrm{R}}\left({ }^{\circ} \rho^{\circ}\right)$ & $\Delta \theta\left(^{\circ}\right)$ & $\theta_{\mathrm{T}}\left(^{\circ}\right)$ & 文献 \\
\hline $\mathrm{Si}$ & $\begin{array}{l}\mathrm{Cl}\left(\mathrm{SiMe}_{2} \mathrm{O}\right){ }_{\mathrm{n}} \mathrm{SiMe}_{2} \mathrm{Cl}(\mathrm{n}=0,1,2,3) \\
\text { 気相処理 }\left(60-70^{\circ} \mathrm{C}\right)\end{array}$ & $1,2,3$ & $\begin{array}{l}(1) \sim 105 / \sim 104, \quad(2) \sim 74 / \sim 72, \\
(3) \sim 36 / \sim 35\end{array}$ & $1-2$ & - & 48 \\
\hline $\mathrm{Si}$ & $\begin{array}{l}\left(\mathrm{Me}_{3} \mathrm{SiO}\right)_{3} \mathrm{SiCH}_{2} \mathrm{CH}_{2} \mathrm{Si}\left(\mathrm{CH}_{3}\right)_{2} \mathrm{Cl} \\
\text { 液相処理 (トルエン, 室温) }\end{array}$ & $1,2,3$ & $\begin{array}{l}\text { (1) } 104 / 103, \quad \text { (2) } 71 / 66 \\
\text { (3) } 38 / \sim 36\end{array}$ & $1-5$ & - & 48 \\
\hline $\mathrm{Si}$ & $\begin{array}{l}\left(\mathrm{Me}_{3} \mathrm{SiO}\right)_{2} \mathrm{Si}\left(\mathrm{CH}_{3}\right) \mathrm{CH}_{2} \mathrm{CH}_{2} \mathrm{Si}\left(\mathrm{CH}_{3}\right)_{2} \mathrm{Cl} \\
\text { 気相処理 }\end{array}$ & $1,2,3$ & (1) $106 / 105$, , (2) $70 / 64$, , (3) $30 / 26$ & $1-6$ & - & 48 \\
\hline $\mathrm{Al}$ & $\begin{array}{l}\left(\mathrm{CF}_{3}\left(\mathrm{CF}_{2}\right)_{5} \mathrm{CH}_{2} \mathrm{CH}_{2} \mathrm{Si}\left(\mathrm{CH}_{3}\right)_{2} \mathrm{O}\right)_{2} \mathrm{SiCH}_{3} \mathrm{H} \\
\text { 気相処理 }\left(150{ }^{\circ} \mathrm{C} \times 72 \mathrm{~h}\right)\end{array}$ & 1,3 & (1) $110 / 109$, , (3) $52 / 50$ & $1-2$ & - & 51 \\
\hline $\mathrm{Si}$ & $\begin{array}{l}\text { PDMS (分子量 : } 2000,9430 \mathrm{~g} / \mathrm{mol}) \\
\text { 加熱処理 }\left(100-150^{\circ} \mathrm{C} \times 24 \mathrm{~h}\right)\end{array}$ & $1,2,3$ & $\begin{array}{l}\text { (1) } 104-106 / 102-105 \\
\text { (2) } 76 / 73-74, \quad \text { (3) } 36 / 33-35\end{array}$ & $1-3$ & - & 61 \\
\hline $\mathrm{Al}, \mathrm{Ti}$ & $\begin{array}{l}\mathrm{C}_{4} \mathrm{H}_{16} \mathrm{O}_{4} \mathrm{Si}_{4} \\
\text { 気相処理 }\left(80^{\circ} \mathrm{C} \times 72 \mathrm{~h}\right)\end{array}$ & 1,3 & $\begin{array}{l}\text { (1) } 104 / 102(\mathrm{Al}), \quad 102 / 99(\mathrm{Ti}) \\
\text { (3) } 33 / 31(\mathrm{Al}), \quad 31 / 28(\mathrm{Ti})\end{array}$ & $2-3$ & - & 32 \\
\hline $\mathrm{Si}$ & $\begin{array}{l}\text { PDMS (分子量 : } 6000 \mathrm{~g} / \mathrm{mol}) \\
\text { 液相処理 }\left(\text { ヘキサン, } 50{ }^{\circ} \mathrm{C} \times 72 \mathrm{~h}\right)\end{array}$ & $1,2,3,4$ & $\begin{array}{l}\text { (1) } 108.8 / 104.2, \quad \text { (2) } 72.7 / 67.9 \text {, } \\
\text { (3) } 34.5 / 32.5, \quad \text { (4) } 21.4 / 19.3\end{array}$ & $2.0-4.8$ & $\begin{array}{l}\text { (1) } 18.7 \\
\text { (2) } 9.7 \\
\text { (3) } 5.0 \\
\text { (4) } 3.8\end{array}$ & 52 \\
\hline $\mathrm{Si}$, ガラス & $\begin{array}{l}\left.\left(\mathrm{CH}_{3}\right)_{2} \mathrm{Si}\left(\mathrm{OCH}_{3}\right)_{2}\right) \\
\text { 液相処理 }(\text { イソプロピルアルコール+硫酸, 室 } \\
\left.\text { 温 } \times \sim 20 \text { min or } 75^{\circ} \mathrm{C} \times \sim 20 \mathrm{~s}\right)\end{array}$ & $1,2,3,5,6,7,8$ & $\begin{array}{l}\text { (1) } 104.6 / 103.6, \quad \text { (2) } 71.2 / 79.2, \\
\begin{array}{ll}\text { (3) } 38.6 / 38.2, & \text { (5) } 19.6 / 19.6, \\
\text { (6) } 32.0 / 31.8, & \text { (7) } 22.8 / 22.6, \quad \text { (8) } 9.4 / 9.4\end{array}\end{array}$ & $0-1.0$ & $\begin{array}{l}\text { (1) } 8 \\
\text { (2) } 4 \\
\text { (3) } 3 \\
\text { (5) } 1 \\
\text { (6) } 2 \\
\text { (7) } 1 \\
\text { (8) } 1 \\
\end{array}$ & 62 \\
\hline
\end{tabular}

* $1:$ 水, $2: \exists ウ$ 化メチレン, $3: n$-ヘキサデカン, $4: n$-ドデカン, $5: n$-デカン, $6:$ トルエン, $7:$ シクロヘキサン, $8: n$-ヘキサン

なように，超撥液処理では有機フッ素化合物が主として用い られていることがわかる。我々の開発した手法の多くは2) に分類され，表 3 に示すように，長鎖有機フッ素化合物では なくユビキタス (汎用)元素(具体的にはアルキル基終端分子) を主として利用することが大きな特長である。したがって, 表面張力の低い液体 (30 dyn/ $\mathrm{cm}$ 以下) を処理表面に垂らすと, 液滴は一見，濡れ広がっているように見える $\left(\theta_{\mathrm{S}}<40^{\circ}\right)$ 。こ れまでの濡れ性の評価基準である $\theta_{\mathrm{S}}$ だけで判断すると，ま ぎれもなく親液性表面である。しかし, 接触角ヒステリシス が小さいため $\left(\Delta \theta<5^{\circ}\right)$, 基板をわずかに傾けるだけで液滴 はテールを引くことなくスムーズに滑落していく。また，長 鎖有機フッ素化合物を用いない理由は, 近年の有機フッ素化 合物の製造に必要な蛍石の価格高騰や長鎖有機フッ素化合物 (特にパーフルオロオクタン酸)の規制を考慮したもので ${ }^{63) ~ 64), ~}$
省エネルギー・省資源・低環境負荷の観点からも，長鎖有機 フッ素化合物に依存しない撥液処理技術の開発は産業界から も強く望まれている。

\section{1 超撥液処理}

1997 年, 辻井らは, 油(菜種油 $\left.\left(\gamma_{\mathrm{LV}}=35 \mathrm{dyn} / \mathrm{cm}\right)\right)$ の $\theta_{\mathrm{S}}$ が $150^{\circ}$ を超える超撥液表面の作製に世界で初めて成功した ${ }^{9)}$ 。 彼らは陽極酸化した $\mathrm{Al}$ を, fluorinated monoalkylphosphate $\left(\mathrm{CF}_{3}\right.$ $\left.\left(\mathrm{CF}_{2}\right)_{9} \mathrm{OP}(=\mathrm{O})(\mathrm{OH})_{2}\right)$ のエタノール溶液に浸漬して表面処 理した。得られた表面の撥液性はプローブ液体の表面張力に 依存し，表面張力が小さくなるに従い低下し，オクタン $\left(\gamma_{\mathrm{LV}}\right.$ $=23 \mathrm{dyn} / \mathrm{cm})$ では $\theta_{\mathrm{S}}$ は $120^{\circ}$ まで減少した。それから 10 年が 経過した 2007 年の Tuteja らの報告 ${ }^{10)}$ をきっかけに, 超撥液 性に関する研究が世界的に脚光を浴びるようになった。彼ら は $\mathrm{SiO}_{2}$ を被覆した $\mathrm{Si}$ 基板に, 二段階エッチングにより 
Micro-hoodoos と呼ばれる構造を形成した後, フルオロアル キルシラン (FAS17, 1H,1H,2H,2H-perfluorodecyltrichlorosilane, $\left.\mathrm{CF}_{3}\left(\mathrm{CF}_{2}\right)_{7} \mathrm{CH}_{2} \mathrm{CH}_{2} \mathrm{SiCl}_{3}\right)$ の蒸気で表面処理した ${ }^{10)}$ 。得られた 表面は $n$-オクタンに対して超撥液性 $\left(\theta_{\mathrm{A}} / \theta_{\mathrm{R}}=163^{\circ} / 145^{\circ}\right)$ を 示した。しかし, 接触角ヒステリシス $\left(\Delta \theta=18^{\circ}\right)$ が大きいた め, $10 \mu \mathrm{L}$ の $n$-オクタンの転落角 $\left(\theta_{\mathrm{T}}=15^{\circ}\right)$ は比較的大きな 值となった。彼らはまた, パーフルオロアルキル基で終端さ れた polyhedral oligomeric silsesquioxane (POSS, $\left(\mathrm{R}-\mathrm{SiO}_{1.5}\right)_{8}, \mathrm{R}$ $=\mathrm{CF}_{3}\left(\mathrm{CF}_{2}\right)_{7} \mathrm{CH}_{2} \mathrm{CH}_{2}$ ) と架橋した poly (dimethylsiloxane) (PDMS) を原料に用い, エレクトロスピニング(電解紡系法) により金属メッシュや $\mathrm{Al}$ 基板にコーティングし，様々な液 体 (有機 / 無機, 極性 / 非極性, ニュートン液体 / 非ニュート ン液体)をはじき, 強酸や強アルカリに対しても安定な超撥 液表面の作製にも成功している ${ }^{20)}$ 。彼らはRe-entrant curvatures (凹の湾曲構造)が超撥液性を発現させるために重 要な役割を果たしていると報告している。Zhangらは trichloromethylsiane $\left(\mathrm{CH}_{3} \mathrm{SiCl}_{3}\right)$ をトルエン中で加水分解 / 縮合 反応させる際，水分量を制御することで様々な微細構造を持 つシリコーンナノフィラメントを作製した ${ }^{15)}$ 。酸素プラズ マによる酸化 $\left(\mathrm{SiO}_{2}\right.$ への変換) と FAS17 を用いた気相処理に より, 得られたナノフィラメントは表面張力の低い液体 $\left(30 \mathrm{dyn} / \mathrm{cm}\right.$ 以下) に対して超撥液性 $\left(\theta_{\mathrm{S}}=157-174^{\circ}\right)$ と優れ た滑落性 $\left(\theta_{\mathrm{T}}=1.2-5.7^{\circ}\right)$ を示した。しかし, $\mathrm{SiO}_{2}$ ナノフィ ラメントという特異な微細構造から機械的強度に課題がある としている。これに対し Dengらは, 蝋燭の煤をテンプレー トに用いることで透明性と機械的強度を兼ね備えた超撥液表 面を作製することに成功している ${ }^{19)}$ 。蝉燭の煤をガラスや $\mathrm{Si}$ 基板上に堆積させた後, アンモニアを触媒として, tetraethoxysilane $\left(\mathrm{Si}\left(\mathrm{OC}_{2} \mathrm{H}_{5}\right)_{4}\right)$ を気相中で加水分解/縮合反応 させ, 煤表面に厚さ $20 \pm 5 \mathrm{~nm}$ の $\mathrm{SiO}_{2}$ 層を形成した。その後, $600{ }^{\circ} \mathrm{C}$ で 2 時間焼成することでテンプレートの煤を酸化除去 した後, (tridecafluoro-1,1,2,2-tetrahydrooctyl)-1-trichlorosilane $\left(\mathrm{CF}_{3}\left(\mathrm{CF}_{2}\right)_{5} \mathrm{CH}_{2} \mathrm{CH}_{2} \mathrm{SiCl}_{3}\right)$ により気相処理した。得られた皮膜 は透明で, 各種液体 (水, ヨウ化メチレン, エチレングリコー ル, $n$-ヘキサデカン, $n$-テトラデカン, オリーブ/ピーナッ ツオイル等)に対して超撥液性 $\left(\theta_{\mathrm{S}}>150^{\circ}\right)$ を示した。また, 接触角ヒステリシス $\left(\Delta \theta=2-6^{\circ}\right)$ が小さいため滑落性 $\left(\theta_{\mathrm{T}}\right.$ $\left.=1-5 \pm 1^{\circ}\right)$ にも優れており, 落砂による衝撃テスト後も, $n$-ヘキサデカンに対して超撥液性 $\left(\theta_{\mathrm{S}}=154^{\circ}\right)$ と滑落性 $\left(\theta_{\mathrm{T}}\right.$ $\left.=5^{\circ}\right)$ を維持していた。

この他にも, 各種金属 / 合金の陽極酸化 ${ }^{14), 16), 17)}, \mathrm{Al}$ の化 学エッチング / 熱水処理 ${ }^{18), 24)}$, ガラスのリアクティブイオン エッチング / 燃焼 CVD による階層構造ナノピラー形成 ${ }^{25)}$, 酸化物ナノ粒子 ${ }^{11) ~ 13), 22), 28) / ナ ノ ワ イ ヤ ー ~}{ }^{26)}$ や針状結晶の堆 積 ${ }^{31)}$, Re-entrant 構造マイクロピラー形成 ${ }^{21,29)}$, 化学処理に よる酸化物ナノワイヤー形成 ${ }^{26)}$, 溶媒誘起結晶化によるポ リマーの Re-entrant 構造形成 ${ }^{30}$ 等, 様々な材料やプロセスを 用いて表面を微細構造化した後, 各種有機フッ素化合物で処 理する手法が報告されている。最近, Wang らがこれまでに 報告されているナノ粒子 / バインダーを利用した代表的な超 撥液処理とその表面特性についてまとめているが ${ }^{28)}, 30 \mathrm{dyn} /$ $\mathrm{cm}$ 以下の表面張力の低い液体に対して, 前述の超撥液性の
定義を満たす事例は極めて少なく, 蓮の葉上の水滴のように 表面張力の低い液体が滑落する表面を作製することがいかに 困難であるかを窥い知ることができる。

このような人工表面に対し, 自然界には表面構造だけで水 や有機液体 (極性/非極性)に濡れない撥液性を備えた生物 (例えばトビムシ) が存在する ${ }^{7}$ 。 。穴特異な表面構造を模倣 したという直接の記載はないが，Liuらは，トビムシの表皮 に似た構造を $\mathrm{SiO}_{2} / \mathrm{Si}$ のリアクティブイオンエッチングによ り, “Doubly re-entrant structures (2 重の凹構造)”を持つマイ クロポストを作製した ${ }^{27)}$ 。表面は $\mathrm{SiO}_{2}$ (親水性)であるにも 関わらず，パーフルオロヘキサン $\left(\mathrm{C}_{6} \mathrm{~F}_{14}, \gamma_{\mathrm{LV}}=10 \mathrm{dyn} / \mathrm{cm}\right) に$ 対して超撥液性 $\left(\theta_{\mathrm{A}} / \theta_{\mathrm{R}}=153.8 \pm 2.2^{\circ} / 133.0 \pm 5.4^{\circ}\right)$ と優れ

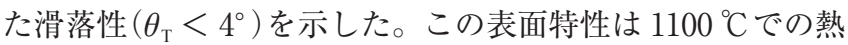
処理後も劣化しなかった。また，同マイクロポスト表面に金 属(タングステン)やポリマー(パリレン)を被覆した場合でも 同様の超撥液性を示すことを確認している。表面の化学特性 （表面エネルギー）に依存せず，表面構造だけで超撥液性を実 現したはじめての事例である。このような複雑な微細構造を トップダウンプロセスに依存せず，いかに簡便に作製するか が課題であり，今後の研究の展開が期待される。

次に，接触角を大きくして接触面積を小さくすることに焦点 を充てた超撥液処理とは異なり，接触角の大きさではなく，液 滴の滑落性に着目した研究を紹介する。液滴の滑落性に着目し た撥液処理では, 低揮発性の液体膜 (フッ素系潤滑液, イオン 液体，シリコーンオイル ${ }^{39) \sim 47)}$ や Liquid-like 膜 ${ }^{32), 37), 48) \sim 62)}$ が 主に使用されている。

\section{2 液体の滑落性に着目した撥液処理 (液体膜)}

Wong らは食虫植物のウツボカズラの捕虫器内壁(微細な 溝があり, 常時, 水膜で覆われているため, 昆虫の脚の油は この水膜によってはじかれ, 捕虫器に溜まった消化液の中に 落下する)を模倣し, 接触角ヒステリシスが小さく液滴の滑 落性に優れた撥液表面, “Slippery Liquid-Infused Porous Surface(s) (SLIPS)”を作製した ${ }^{39)} 。$ 彼らはFAS17 で表面処 理したエポキシ樹脂製ナノポストアレイ，テフロン製多孔質 ナノファイバー網に 3 種類のフッ素系潤滑液 (FC-70, Krytox $\left.{ }^{\circledR} 100,103\right)$ を充填して SLIPS を作製した。この SLIPS は, 水, 炭化水素系液体, 原油, 血液など様々な液体に対し て接触角ヒステリシスが小さく $(\Delta \theta<2.5)$, 優れた滑落性 $\left(\theta_{\mathrm{T}} \leqq 5^{\circ}\right)$ と自己修復性を示した。また, 〜 676 気圧の高圧下， $-4{ }^{\circ} \mathrm{C}$ の低温下でも安定で, それぞれの測定条件下で $n$ - デ カンや水がスムーズに滑落すると報告している。Maらはア ルミナゲル膜を熱水処理してナノ構造化し, $1 \mathrm{H}, 1 \mathrm{H}, 2 \mathrm{H}, 2 \mathrm{H}-$ perfluorodecylphosphonic acid $\left(\mathrm{CF}_{3}\left(\mathrm{CF}_{2}\right)_{5} \mathrm{CH}_{2} \mathrm{CH}_{2} \mathrm{P}(=\mathrm{O})(\mathrm{OH})_{2}\right)$ で 表面処理した後, パーフルオロポリエーテル $\left(\right.$ Fomblin $\left.{ }^{\circledR} \mathrm{Y}\right)$ を 充填して透明性の高いSLIPS を作製した ${ }^{40)}$ 。得られた SLIPS は, 水, アセトン, THF, トルエン, $n$-ヘキサデカンに対し て接触角ヒステリシス $\left(\Delta \theta=2-6^{\circ}\right)$ が小さく優れた滑落性 $\left(\theta_{\mathrm{T}}<5^{\circ}\right)$ を示した。また, タンパク質や指紋も付着しにくく, 6 ケ月以上の屋外暴露後も滑落性は変化しなかった。 Manabe らは, $\mathrm{SiO}_{2}$ ナノ粒子とキチンナノファイバーを用いた交互 積層法により，透明で反射防止機能を持った 3 種類の生物模 
倣表面(蛾の目（モスアイ），蓮の葉，食虫植物）を作製し，そ の表面特性を調べている ${ }^{41}$ 。 モスアイを模倣した表面(表面 処理なし) は超親水性と防是性があり, 蓮の葉模倣表面(パー フルオロアルキルシランによる表面処理あり)は超撥水性と 霜付着抑制能があった。この蓮の葉模倣表面にパーフルオロ ポリエーテル $\left(\operatorname{Krytox}^{\circledR}\right.$ GPL 103)を充填して作製した SLIPS は, 優れた滑落性 (水: $\theta_{\mathrm{T}}=10^{\circ}$, 油 : $\theta_{\mathrm{T}}=2-5^{\circ}$ ) と霜付着 抑制能 / 除去性があると報告している。

SLIPS のような液体膜表面は平滑性が高く, 接触角ヒステリ シスも小さいため優れた滑落性，自己修復性を示すが，潤滑液 を保持するために基材の微細構造化 (多孔質媒体) と表面処理が 必要であり, 潤滑液の揮発, 不純物の付着, 流動性の高い環境 下での使用が困難等，実環境下での使用には制限がある。この ような背景から, Zhang らは最近, 潤滑液の揮発が滑落性, 透 明性，セルフクリーニング性能に及ぼす影響を詳細に調べてい る ${ }^{42)}$ 。著者らは，潤滑液の揮発という SLIPS の課題を解決す るために, 不揮発性のイオン液体に着目した。アミノシランで 処理したシリカ系多孔質媒体にフッ素系イオン液体，(1-ethyl3-methylimidazolium bis (trifluoromethylsulfonyl)imide) を充填 しSLIPS を作製した ${ }^{43)}$ 。試料を極限環境下, 真空 $(0.7 \mathrm{~Pa}$ で 24 時間放置), 高温 $\left(250{ }^{\circ} \mathrm{C}\right.$ で 12 時間放置), 真空紫外光 $\left(10^{3} \mathrm{~Pa}\right.$ で 20 分照射) )に放置した後も動的濡れ性に大きな変 化はなく, 各種液体 (水, ヨウ化メチレン, $n$-ヘキサデカン) に対して優れた滑落性 $\left(\theta_{\mathrm{T}}<4^{\circ}\right)$ を維持していた。また, Wang らは最近，透明な SLIPS を様々な基板（ガラス，Al フォイル， 紙，木材）上に簡便に作製する手法を提案している ${ }^{44)}$ 。彼ら は $\mathrm{SiO}_{2}$ ナノ粒子とフッ素系メタクリル酸共重合体をアセ卜 ン/ 水に分散させた溶液をはけ塗りによって各種基板上に塗 布した後, パーフルオロポリエーテル $\left(K_{\text {Krytox }}{ }^{\circledR} 100\right)$ を充填 してSLIPS を作製した。この手法は原料にナノ粒子とフッ 素系ポリマーを用いているため, 微細構造化プロセスと表面 処理が不要な上，はけ塗りによる大面積処理も可能という利 点がある。さらに最近では, SLIPSのように微細構造化プロ セスを経ることなく,潤滑液 (イオン液体, シリコンオイル等) を直接ゲルに含浸させる，あるいはゲル前駆液に予め混合し た後にゲル化させることで，透明性と滑落性に優れた撥液表

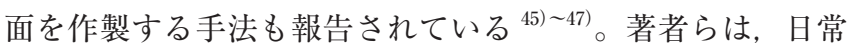
生活でしばしば目にする離漿(りしょう)というゲルから夜体 が押し出される現象(例えば，ヨーグルトの乳清や寒天の表 面に水が浮いてくる現象)を利用した撥液表面を作製した ${ }^{477}$ 。 ヒドロシリル $(\mathrm{Si}-\mathrm{H})$ 基を含む変性シリコーン (PDMS_H) およ びビニルシリル $\left(\mathrm{Si}-\mathrm{CH}=\mathrm{CH}_{2}\right)$ 基を含む変性シリコーン (PDMS V) の混合物 (PDMS 前駆液) に鎖長 (炭素数)の異なる 直鎖状アルカン $\left(\mathrm{C}_{n} \mathrm{H}_{2 n+2} n=10,12,14,16\right)$ を添加し, 白金系 触媒を用いたヒドロシリル化反応によりオルガノゲルを作製 した。試料を室温で放置すると $n=16$ ( $n$-ヘキサデカン)を 用いた場合のみ，数分でゲル表面より液体成分の離漿が観察 された。図 2 に示すように，この試料表面を傾斜させ，ケ チャップやマヨネーズ等の粘性液体を滴下したところスムー ズに滑落した。一方，離漿しないゲル表面 $(n \leqq 14)$ では，こ れらの粘性液体は表面に付着したままであった。これは, 離 漿によりオルガノゲル表面に油膜が形成され, PDMS 樹脂と

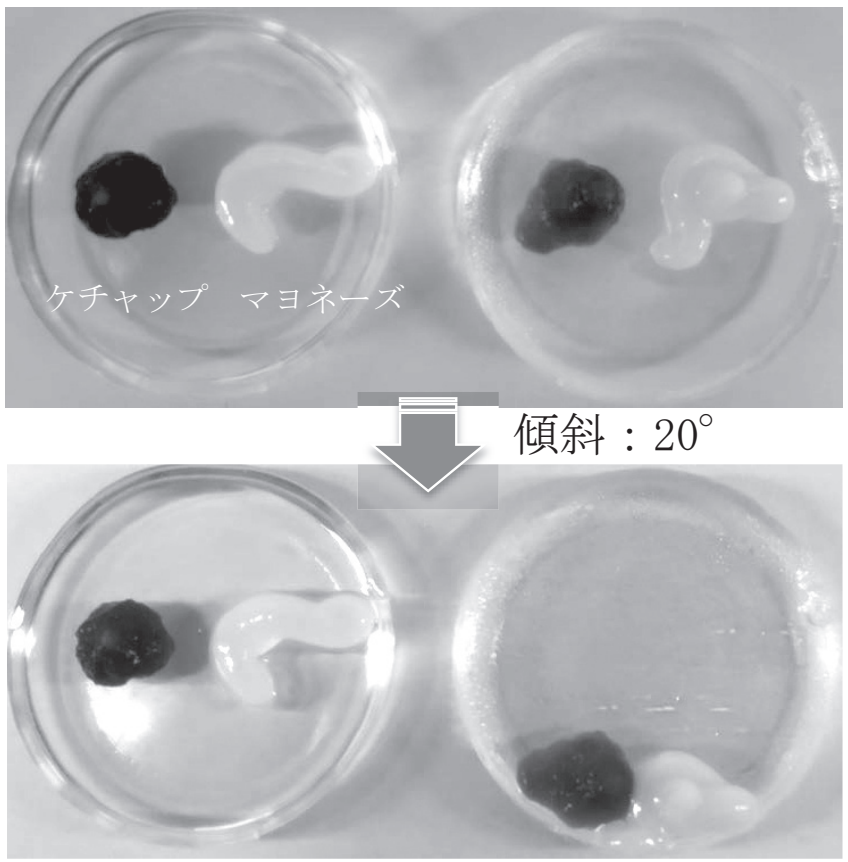

図 2 オルガノゲル (左：離漿なし，右：離漿あり)上の粘性液体の 滑落性の違い

粘性液体との直接的な接触が抑制されたためと考えられる。

\section{3 液体の滑落性に着目した撥液処理 (Liquid-like 膜)}

Liquid-like 膜とは，固体膜ではあるが表面に固定化された 官能基間の距離が離れているため, それらが回転/駆動でき る “Liquid-like (液体のような)”な状態にある膜のことを示 している。McCarthyらは，このような “Liquid-like” な状態 にある表面では，表面官能基の回転 / 駆動により液滴の 3 相 接触線が動きやすくなり, 液滴が動く際のエネルギーバリア が小さくなるため, 接触角ヒステリシスが小さくなるという 仮説を立て，いくつかのモデル表面を作製してその動的濡れ 性について詳細に調べている ${ }^{48) ~ 50)}$ 。しかしながら，基板に は高い平滑性と反応性から $\mathrm{Si}$ 基板が主として用いられ，金 属やポリマーをはじめとするその他の実用的な基板で接触角 ヒステリシスを制御する技術はこれまで確立されていなかっ た。このような Liquid-like 膜は平滑で空気層の効果がないた め, 見かけの接触角の值は比較的小さいが, プローブ液体と 表面との相互作用 (接触角ヒステリシス)が小さいため, 液滴 はピン止めされることなく小さい転落角でスムーズに滑落し ていく。

著者らは McCarthy らの仮説 ${ }^{48)}$-50) を手がかりに, 微細構 造や有機フッ素化合物を利用することなく, 接触角ヒステリ シス制御により液滴の滑落性を向上させる実用的な表面处理 手法を開発し続けてきた。以下に，接触角ヒステリシスが小

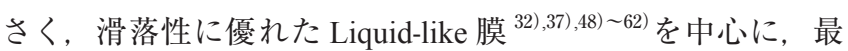
近の研究動向とその表面特性について紹介する。

3. 3.1 単分子膜

枝状や環状等の特殊な分子構造をした有機シランの気相処 理により，水や油に対して接触角ヒステリシスの小さい表面 を作製することができる ${ }^{32,511}$ 。著者らは，電解研磨した $\mathrm{Al}$ 基板を, 枝状構造をもったパーフルオロアルキル基で終端さ れたヒドリドシラン (bis ( (tridecafluoro-1,1,2,2,-tetrahydrooctyl) 
-dimethylsiloxy) methylsilane, $\left\{\mathrm{CF}_{3}\left(\mathrm{CF}_{2}\right)_{5} \mathrm{CH}_{2} \mathrm{CH}_{2} \mathrm{Si}\left(\mathrm{CH}_{3}\right)_{2} \mathrm{O}\right\}_{2}$ $\left.\mathrm{SiCH}_{3} \mathrm{H}\right)$ の蒸気で $150{ }^{\circ} \mathrm{C}, \sim 72$ 時間, 気相処理し, 水にも 油に対しても接触角ヒステリシスの小さい表面 $\left(\theta_{\mathrm{A}} / \theta_{\mathrm{R}}=110^{\circ}\right.$ $/ 109^{\circ}$ (水), $52^{\circ} / 50^{\circ}$ ( $n$-ヘキサデカン))を作製した ${ }^{51)}$ 。この 処理により, 約 $1 \mathrm{~nm}$ の単分子膜が形成していることがXPS により確認された。この表面は水や油に対してさほど大きな 接触角を示すわけではないが，基板をわずかに傾けたけで液 滴はスムーズに流れ落ちる。接触角ヒステリシスによる 3 相 接触線の “ピン止め”がない。金属(平滑)表面を低ヒステリ シス化したはじめての事例といえる ${ }^{51)}$ 。また, この試料は 1 ケ 月に渡る耐水試験後も動的接触角は変化せず, さらには, 塩 水噴霧試験 (JIS Z 2371) 1000 時間後も金属光沢は失われず優 れた防食性能を示した。この他にも，環状構造を持った (1,3,5,7-tetramethylcyclotetrasiloxane, $\mathrm{C}_{4} \mathrm{H}_{16} \mathrm{O}_{4} \mathrm{Si}_{4}$, 以下, $\mathrm{D}_{4}{ }^{\mathrm{H}}$ と 示す。)も同様の気相処理により, Si 表面だけでなく, 酸化 膜で覆われた金属 $(\mathrm{Al}, \mathrm{Ti}, \mathrm{Cu}, \mathrm{Fe})$ やセラミックス (ジルコ ニア) 表面にも $\mathrm{D}_{4}{ }^{\mathrm{H}}$ 由来の単分子膜(膜厚 $0.5 \mathrm{~nm}$ ) が形成し, 接触角ヒステリシスの小さい表面ができることを確認してい る ${ }^{32)}$ 。一例として, $\mathrm{D}_{4}{ }^{\mathrm{H}}$ 単分子膜を被覆した $\mathrm{Al}$ と $\mathrm{Ti}$ 表面の 動的接触角 $\left(\theta_{\mathrm{A}} / \theta_{\mathrm{R}}\right)$ は，水がそれぞれ，104 $/ 102^{\circ}, 102^{\circ} / 99^{\circ}$, n-ヘキサデカンがそれぞれ， $33^{\circ} / 31^{\circ} ， 31^{\circ} / 28^{\circ}$ となった。水 にも油に対しても接触角ヒステリシスが極めて小さいため, 液滴は $\mathrm{D}_{4}{ }^{\mathrm{H}}$ 単分子膜表面をわずかな傾斜で滑落した。

\section{3. 2 PDMS 薄膜}

Joseph らは, trimethylsilyl 基終端の非反応性 PDMS (分子量: 311，770，2000，9430，116 K g/mol）の原液を, 酸素プラズ マで洗浄した $\mathrm{Si}$ 基板, $\mathrm{Ti}, \mathrm{Al}, \mathrm{Ni}$ を被覆した $\mathrm{Si}$ 基板表面に 垂らし， $100 \sim 150{ }^{\circ} \mathrm{C}$ で 24 時間，加熱処理することにより 滑落性に優れたPDMS 薄膜を作製した ${ }^{61)}$ 。膜厚は分子量に 依存し， $0.47 〜 12.48 \mathrm{~nm}$ であった。また，接触角ヒステリ シスも同様に分子量に依存し，分子量：2000, $9430 \mathrm{~g} / \mathrm{mol}$ の PDMS で処理した場合, 水, ヨウ化メチレン, $n$-ヘキサデカ ンの動的接触角 $\left(\theta_{\mathrm{A}} / \theta_{\mathrm{R}}\right)$ はそれぞれ, $104 \sim 106^{\circ} / 102 \sim 105^{\circ}$, $76^{\circ} / 73 \sim 74^{\circ}, 36^{\circ} / 33 \sim 35^{\circ}$ となり, 接触角ヒステリシス が最も小さくなった $\left(\Delta \theta \leqq 3^{\circ}\right)$ 。しかし, 金属酸化物表面では, 同じ条件で処理したにも関わらず，水の接触角ヒステリシス は大きくなった。彼らは, 用いたPDMS が非反応性である にも関わらず, $\mathrm{Si}\left(\mathrm{SiO}_{2}\right)$ 表面と共有結合を介して固定化され た理由について，1） $\mathrm{Si}\left(\mathrm{SiO}_{2}\right)$ 表面の吸着水による PDMS の 加水分解とそれに続く, シラノール $(\mathrm{Si}-\mathrm{OH})$ 基間での脱水縮 合反応, 2) $\mathrm{SiO}_{2}$ の酸触媒作用により生成したシラノレート $\left(\mathrm{Si}^{-} \mathrm{O}^{-}\right)$基の $\mathrm{PDMS} へ の$ 求核反応による直接結合 (silanolysis), の二つの反応が寄与していると推測している。

著者らは, PDMS ブラシにより優れた滑落性を付与する表 面改質技術を開発した ${ }^{37), 52)}$ 。前述の $\mathrm{D}_{4}{ }^{\mathrm{H}}$ 単分子膜被覆表面 ${ }^{32)}$ に残存したヒドリド $(\mathrm{Si}-\mathrm{H})$ 基を利用して“grafting to”法によ り, ビニル基終端 PDMS (Gelest 製, 分子量 : $6000 \mathrm{~g} / \mathrm{mol}$ )を Karstedt 触媒を用いたヒドロシリル化反応によりエチレン基 を介して表面に固定化した。PDMS を $n$-へキサンに希釈し た後, Karstedt 触媒 $(10 \mathrm{ppm})$ を添加して反応溶液 $(20 \mathrm{wt} \%)$ を 調整し, 前述の $\mathrm{D}_{4}{ }^{\mathrm{H}}$ 単分子膜を被覆した $\mathrm{Si}$ 基板を反応溶液 $\left(50{ }^{\circ} \mathrm{C}\right)$ に 72 時間浸漬したところ, 膜厚約 $3 \mathrm{~nm}$ の PDMS ブ
ラシが基板表面に固定化されていることが赤外高感度反射法 とエリプソメータにより確認された。PDMS ブラシ被覆表面 は平滑で接触角ヒステリシスが小さく，例えば，微小油滴 $(3$ $\mu \mathrm{L}$ の-デカン)に対しても優れた滑落性 $\left(\theta_{\mathrm{T}}=1^{\circ}\right)$ を示した。 この值は, 先に述べた $\theta_{\mathrm{S}}$ が $160^{\circ}$ を超える超撥液表面上の $n$ デカン $(5 \mu \mathrm{L})$ の転落角 $\left(\theta_{\mathrm{T}}=5.3^{\circ}\right)$ よりもはるかに小さい。 “grafting to”法は，材料表面に固定された高分子鎖による立 体障害により, 反応が一定の限界值を超えて進行しない。そ のため, ブラシ密度が低く, Liquid-like な状態になっている と考えられる。また, この PDMS ブラシ被覆表面の動的濡 れ性は温度により著しく変化した。基板を $70{ }^{\circ} \mathrm{C} に$ 加熱する と高分子鎖の動きが活発になるため, 接触角ヒステリシス, 転落角ともに著しく小さくなることを確認している ${ }^{52)}$ 。

また, 最近, 著者の一人であるWang らは, 優れた滑落性 を示す PDMS 薄膜を極めて短時間で作製する手法を報告し ている ${ }^{62)}$ 。Dimethyldimethoxysilane $\left(\left(\mathrm{CH}_{3}\right)_{2} \mathrm{Si}\left(\mathrm{OCH}_{3}\right)_{2}\right)$ をイソ プロピルアルコールに溶解し, 硫酸を触媒として添加し調整 した反応溶液に $\mathrm{Si}$ 基板をディップコートすることにより, 数十分程度 (加熱すれば数十秒) の反応時間で膜厚 $3 \sim 4 \mathrm{~nm}$ のPDMS 薄膜が形成すると報告している。得られたPDMS 表面 (Slippery Omniphobic Covalently Attached Liquid(SOCAL) surfaces) は優れた滑落性を示し, 例えば, $n$-ヘキサンの動的 接触角 $\left(\theta_{\mathrm{A}} / \theta_{\mathrm{R}}\right)$ は $9.4^{\circ} / 9.4^{\circ}$ と小さいにも関わらず, 接触角ヒ ステリシスがないため，わずかな傾斜 $\left(\theta_{\mathrm{T}}=1^{\circ}(5 \mu \mathrm{L})\right)$ で滑 落した(図 3)。また, 耐熱性にも優れ, 大気中で熱処理 $\left(100{ }^{\circ} \mathrm{C}\right.$, 1000 時間) した後も, 水の動的濡れ性に大きな変化は確認さ れなかった。

\section{3. 3 ゾルーゲルハイブリッド皮膜}

前述の単分子膜や PDMS 薄膜の膜厚は極めて薄い 0.5 $13 \mathrm{~nm}$ 程度)ため, 基板のラフネスが動的濡れ性に著しく影 響を及ぼす。そのため, 平滑で欠陥のない基板（通常は $\mathrm{Si}$ 基 板)が必要不可欠であった。我々は様々な実用基板の表面処 理を視野に入れ, 基板のラフネスの影響を受けない膜厚で成 膜することが可能なゾルーゲル法に着目した ${ }^{53) ~ 60) 。 ~}$

鎖長の異なるアルキル基終端有機シラン $\left(\mathrm{C}_{n} \mathrm{H}_{2 n+1} \mathrm{Si}\right.$ $\left(\mathrm{OC}_{2} \mathrm{H}_{5}\right)_{3}, n=3,6,8,10,12,14,16$ and 18) に, その

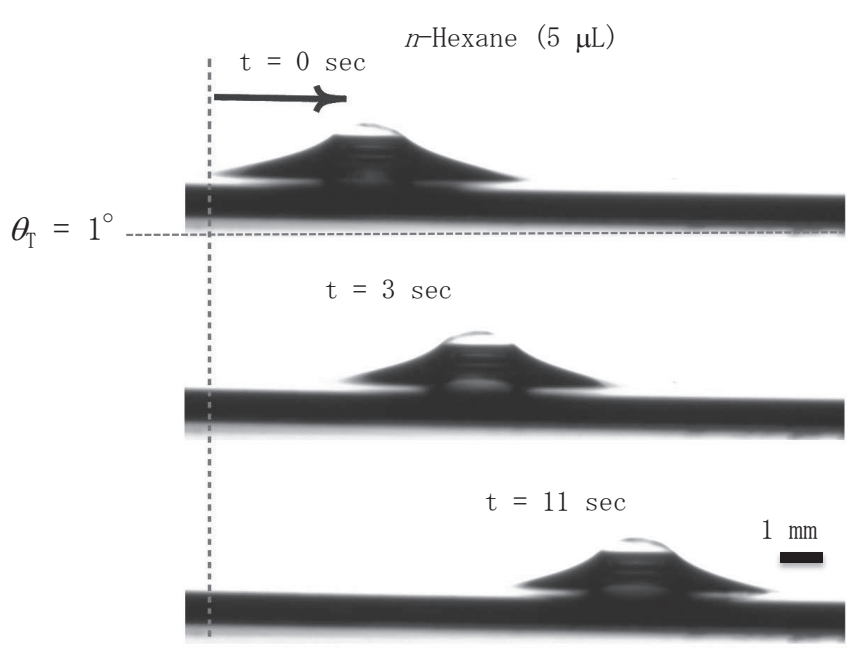


表 4 各種液体に対する $\mathrm{C}_{10} / \mathrm{TMOS}$ ハイブリッド皮膜(上段) と $\mathrm{C}_{10}$ 単分子膜 (下段)の動的接触角 $\left(\theta_{\mathrm{A}} / \theta_{\mathrm{R}}\right)$, 接触角ヒステリ シス $\left(\Delta \theta=\theta_{\mathrm{A}}-\theta_{\mathrm{R}}\right)$, 転落角 $\left(\theta_{\mathrm{T}}\right.$, 液量 : $\left.5 \mu \mathrm{L}\right)$

\begin{tabular}{|c|c|c|c|c|}
\hline プローブ液体 & $\begin{array}{l}\text { 表面張力 } \\
\text { (dyn/cm) }\end{array}$ & $\begin{array}{l}\theta_{\mathrm{A}} / \theta_{\mathrm{R}} \\
\left({ }^{\circ} /{ }^{\circ}\right)\end{array}$ & $\begin{array}{l}\Delta \theta \\
\left(^{\circ}\right)\end{array}$ & $\begin{array}{l}\theta_{\mathrm{T}} \\
\left({ }^{\circ}\right)\end{array}$ \\
\hline 水 & 72.8 & $\begin{array}{c}109 / 100 \\
109 / 86\end{array}$ & $\begin{array}{c}9 \\
23\end{array}$ & $\begin{array}{l}40 \\
90\end{array}$ \\
\hline ジョードメタン & 50.8 & $\begin{array}{l}73 / 71 \\
65 / 59 \\
\end{array}$ & $\begin{array}{l}2 \\
6\end{array}$ & $\begin{array}{l}6.2 \\
27 \\
\end{array}$ \\
\hline オレイン酸 & 32.8 & $\begin{array}{l}52 / 47 \\
42 / 27 \\
\end{array}$ & $\begin{array}{c}5 \\
15 \\
\end{array}$ & $\begin{array}{l}9.0 \\
57 \\
\end{array}$ \\
\hline 大豆油 & 31.3 & $\begin{array}{l}52 / 47 \\
45 / 27\end{array}$ & $\begin{array}{c}5 \\
18 \\
\end{array}$ & $\begin{array}{l}11 \\
54 \\
\end{array}$ \\
\hline トルエン & 28.4 & $\begin{array}{l}37 / 36 \\
23 / 14\end{array}$ & $\begin{array}{l}1 \\
9\end{array}$ & $\begin{array}{l}2.5 \\
26\end{array}$ \\
\hline p- キシレン & 28.3 & $\begin{array}{l}39 / 37 \\
25 / 14\end{array}$ & $\begin{array}{c}2 \\
11\end{array}$ & $\begin{array}{l}3.2 \\
18\end{array}$ \\
\hline n-ヘキサデカン & 27.5 & $\begin{array}{c}36 / 34 \\
21 / 8\end{array}$ & $\begin{array}{c}2 \\
13\end{array}$ & $\begin{array}{l}3.4 \\
21\end{array}$ \\
\hline テルペン油 & 27.0 & $\begin{array}{c}31 / 31 \\
16 /<5\end{array}$ & $\begin{array}{c}0 \\
--\end{array}$ & $\begin{array}{l}2.7 \\
--\end{array}$ \\
\hline$n$ - ドデカン & 25.4 & $\begin{array}{c}27 / 25 \\
7 /<5\end{array}$ & $\begin{array}{l}2 \\
--\end{array}$ & $\begin{array}{l}2.5 \\
--\end{array}$ \\
\hline$n$ - デカン & 23.8 & $\begin{array}{c}21 / 20 \\
<5 /<5\end{array}$ & 1 & $\begin{array}{l}2.4 \\
--\end{array}$ \\
\hline エタノール & 22.1 & $\begin{array}{c}29 / 25 \\
<5 /<5\end{array}$ & $\begin{array}{l}4 \\
--\end{array}$ & $\begin{array}{l}8.8 \\
---\end{array}$ \\
\hline
\end{tabular}

官能基密度を制御するための“ナノスペーサー”として機能 する tetramethoxysilane (TMOS, $\left.\mathrm{Si}\left(\mathrm{OCH}_{3}\right)_{4}\right)$ を添加して, 表面近 傍のアルキル鎖の運動性を向上させることを試みた ${ }^{53), 54)}$ 。通 常，アルキル基で終端された有機シラン単分子膜で被覆した 表面は高い撥水性を示すが，油に対しては親油性を示す。し かし, 表 4 に示すように, 同じ原料 $\left(n=10\right.$, 以下, $\mathrm{C}_{10}$ と示 す）を用いたにも関わらず，TMOS を添加することにより表 面特性が著しく変化することが明らかとなった。例えば, $\mathrm{C}_{10} / \mathrm{TMOS}$ ハイブリッド皮膜は, トルエン, $n$-ヘキサデカン, n-デカンなど, 表面エネルギーの低い液体に対して接触角ヒ ステリシス $\left(\Delta \theta=1-2^{\circ}\right)$ が小さく優れた滑落性 $\left(\theta_{\mathrm{T}}<4^{\circ}\right)$ を 示した。しかし，鎖長が長くなるに従い $(n>12)$, 動的撥液 性は著しく低下する傾向が観察された。鎖長が短い場合 $(n$ <12)，アルキル鎖は Liquid-like な挙動をするのに対し，鎖 長が長くなるに従い，官能基間の相互作用が強くなり，官能 基の運動性が低下することに加え, 膜の不均一性(クラック や凹凸) が動的撥液性を低下させる原因になったと考えられ る。従って, $n=12$ がアルキル鎖の物理的性質 (Liquid-like か Solid-like) を決定する臨界数であることが示唆された。

本稿の主眼からは外れるが，パーフルオロアルキル基終端 有機シラン $\left(\mathrm{R}_{\mathrm{f}} \mathrm{C}_{2} \mathrm{H}_{4} \mathrm{Si}\left(\mathrm{OC}_{2} \mathrm{H}_{5}\right)_{3},\left(\mathrm{R}_{\mathrm{f}}=\mathrm{CF}_{3}\left(\mathrm{CF}_{2}\right) n, n=0,3,5\right.\right.$, 7）を用いた場合でも上記と同様の効果を確認している ${ }^{55), 57) 。 ~}$ これまで鎖長の短い $(n=0)$ フルオロアルキルシランで処理 された表面は撥油性が低いと信じられてきた。我々の手法を 用いると，長鎖パーフルオロアルキルシラン $(n=5,7)$ を用 いた場合と同等の滑落性が得られることがわかった。著者ら は, この他にも, 枝状構造を持ったステアリン酸とジルコニ ウムテトラプロポキシドを用いたゾルーゲル反応により，透 明性, 硬度, 耐熱性を兼ね備えた, 油滴の滑落性に優れた撥 液表面を作製することにも成功している ${ }^{59)}$ 。

このように, 官能基密度を制御して“Liquid-like”な表面 を作製すれば，接触角ヒステリシスが小さくなり液滴の滑落
性が向上することを実験的に検証することができた。

そこで，この “Liquid-like 膜” 表面が優れた滑落性を示すメ カニズムを調べるため, 前述の $\mathrm{C}_{10} / \mathrm{TMOS}$ ハイブリッド皮膜 を用いて, 皮膜最表面(固/気および固 / 液界面)に存在するア ルキル鎖の構造を和周波分光法(Sum-Frequency Generation Spectroscopy, SFG)により調べた ${ }^{60)}$ 。得られた SFG スペク トルと推測される $\mathrm{C}_{10} / \mathrm{TMOS}$ ハイブリッド皮膜の表面官能基 の状態を図 4, 図 5 にそれぞれ示す。図 4 から, $\mathrm{C}_{10} / \mathrm{TMOS}$ ハイブリッド皮膜表面のアルキル鎖が周囲の環境(気体およ び液体の極性)に応じてその配座を変化させていることがわ かる。例えば, アルキル鎖と親和性の高い液体(極性の小さ いアルカン等)が表面に接触するとアルキル鎖配座の秩序性 が向上し，固/液界面ではメチル基 $\left(\mathrm{CH}_{3}{ }^{-}\right)$が支配的になった。 この場合, 図 5 に示すように，3相接触線近傍の固 / 液界面 は固/気表面よりも表面エネルギーが小さくなっている。液 滴は表面エネルギーの低い(接触角の高い) ところから高い （接触角の低い）ところに移動することはできるがその逆はで きない。従って，3相接触線が動く際にエネルギーバリアが ないため，極性の小さい液体は滑落しやすくなる。一方，親 和性の低い液体(極性の大きい水等)ではアルキル鎖の秩序性 が低下しメチレン基 $\left(-\mathrm{CH}_{2^{-}}\right)$が支配的になった。この場合, 固/液界面は固/気表面よりも表面エネルギーが若干大きく なるため液滴は滑落しにくくなり, 大きな転落角が必要となる。

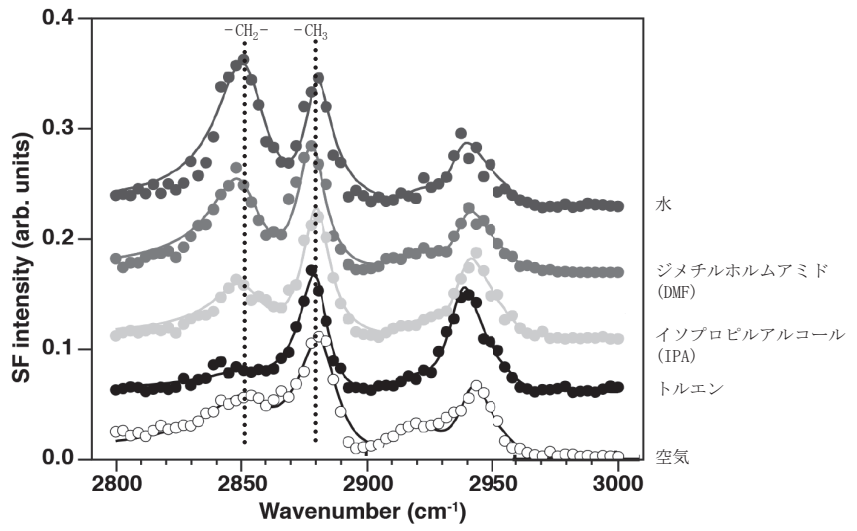

図 4 各種液体が $\mathrm{C}_{10} / \mathrm{TMOS}$ ハイブリッド皮膜に接した際の SFG ス ペクトルの変化

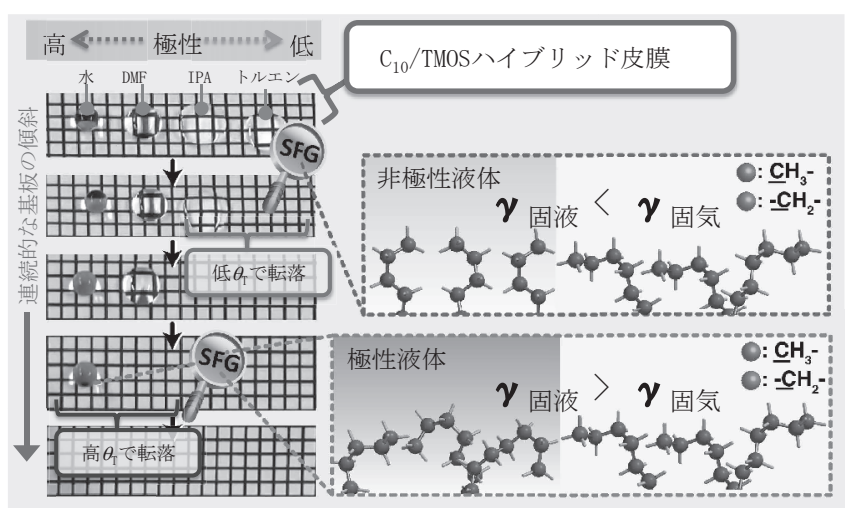

図 $5 \mathrm{C}_{10} / \mathrm{TMOS}$ ハイブリッド皮膜上の各種液滴の滑落性と表面官能 基の配向状態の模式図 
このような配座の変化に伴う表面エネルギーの局所的な変化 が 3 相接触線付近で連続的に起こるため, 極性の低い液体ほ ど $\mathrm{C}_{10} / \mathrm{TMOS}$ ハイブリッド皮膜表面を滑落しやすいことが明 らかとなった。この SFGの結果から, 表面官能基がその配座 を変化させるためのナノ空間が必要であることが示唆され， 滑落性を向上させるには, 官能基の配座変化が可能な “Liquidlike”な表面状態が有効であることが明らかとなった ${ }^{60)}$ 。

\section{4.まとめ}

様々な液体に対して優れた滑落性を付与することが可能な 表面処理技術の最新の研究開発動向と我々の研究事例につい て述べた。産業応用の観点では，水だけでなく表面張力の低 い液体をはじく，あるいはスムーズに滑落させることができ る材料 / 表面の需要は大きい。これまで濡れに関する研究は, 微細構造化と低表面エネルギー化により, 見かけの接触角 (静 的接触角)の值を大きくし, 液滴と固体表面の接触面積を極 限まで小さくすることにのみ焦点が絞られてきたといっても 過言ではない。しかし，水以外の撥液処理に関しては，油や 有機溶剤自身の低い表面張力のために接触角を大きくするこ とは困難であり，環境負荷の大きな長鎖有機フッ素化合物の 使用は必須不可欠であった。また, 従来から指摘されている 微細構造表面の弱点である耐久性の改善や自己治癒 / 修復機 能付与に取り組んだ研究も増えてきてはいるものの ${ }^{16), 22), 31)}$, いずれも根本的な解決に繋がる手法は未だ確立されていない。 実用を見据えた応用へと繋げるためには, 微細構造化と低表 面エネルギー化に依存した既存概念からの脱却と新たなブレ イクスルーが必要である。

これに対し，我々の開発した “Liquid-like 膜”は，低表面 張力液体に対して見かけの接触角が小さいため, 一見, 濡れ ているように見える。しかし，接触角ヒステリシスが小さい ため, 液体はピン止めされることなくスムーズに表面を滑落 していく。また，煩雑な微細構造化プロセスも長鎖有機フッ 素化合物も必要なく, 安価で環境負荷が小さいユビキタス (汎 用)元素だけで優れた滑落性を実現することができる。優れ た滑落性を得るには，接触角を大きくするのではなく，接触 角ヒステリシスを制御することが重要である。また，極めて 限定的な結果ではあるが, 表面官能基の密度が低く, “Liquid-like”な状態にあることが優れた滑落性を得る上で重 要であることもわかってきた ${ }^{60)}$ 。自然や資源に配慮した技 術開発の観点から, 有機フッ素化合物に依存しない撥液処理 技術の開発は，コストだけではなく，現在の社会が抱えてい る資源，エネルギー，環境問題の解決に寄与することが期待 できるため，持続可能性社会を実現する上で今後ますます重 要な研究課題になるであろう。

\section{謝辞}

本研究の一部は科研費 24120005 の助成を受けて行われた。 (Received June 26, 2016)

\section{文献}

1) W. Barthlott, C. Neinhuis ; Planta, 202, 1 (1997).

2 ) X. F. Gao, L. Jiang ; Nature, 432, 36 (2004).
3 ) A. R. Parker, C. R. Lawrence ; Nature, 414, 33 (2001).

4 ) M. Liu, S. Wang, Z. Wei, Y. Song, L. Jiang ; Adv. Mater, 21, 665 (2009).

5 ) 井須紀文; 溶接学会誌, 78, 187 (2009).

6 ) H. F. Bohn, W. Federle ; Proc. Natl. Acad. Sci. USA, 101, 14138 (2004).

7 ) R. Helbig, J. Nickerl, C. Neinhuis, C. Werner ; PLoS ONE, 6, e25105 (2011).

8 ) L. Wen, Y. Tian, L. Jiang ; Angew. Chem. Int. Ed., 54, 3387 (2015).

9 ) K.Tsujii, T. Yamamoto, T. Onda, S. Shibuichi ; Angew. Chem. Int. Ed. Engl., 36, 1011 (1997)

10) A. Tuteja, W. Choi, M. L. Ma, J. M. Mabry, S. A. Mazzella, G. C. Rutledge, G. H. McKinley, R. E. Cohen ; Science, 318, 1618 (2007).

11) B. Leng, Z. Shao, G. de With, W. Ming ; Langmuir, 25, 2456 (2009).

12) C.-T. Hsieh, F.-L. Wu, W.-Y. Chen ; J. Phys. Chem. C, 113, 13683 (2009).

13) A. Steele, I. Bayer, E. Loth ; Nano Lett., 9, 501 (2009).

14) D. Wang, X. Wang, X. Liu, F. Zhou ; J. Phys. Chem. C, 114, 9938 (2010)

15) J. P. Zhang, S. Seeger ; Angew. Chem. Int. Ed., 50, 6652 (2011).

16) X. Wang, X. Liu, F. Zhou, W. Liu ; Chem. Commun., 47, 2324 (2011).

17) T. Fujii, Y. Aoki, H. Habazaki ; Langmuir, 27, 11752 (2011).

18) J. Yang, Z. Zhang, X. Xu, X. Men, X. Zhu, X. Zhou ; New J. Chem., 35, 2422 (2011).

19) X. Deng, L. Mammen, H.-J. Butt, D. Vollmer ; Science, 335, 67 (2012).

20) S. Pan, A. K. Kota, J. M. Mabry, A. Tuteja ; J. Am. Chem. Soc., 135, 578 (2013)

21) K. Golovin, D. H. Lee, J. M. Mabry, A. Tuteja ; Angew. Chem. Int. Ed., 52, 13007 (2013).

22) H. Zhou, H. Wang, H. Niu, A. Gestos, T. Lin ; Adv. Funct. Mater, 23, 1664 (2013).

23) A. K. Kota, G. Kwon, A. Tuteja ; NPG Asia Materials, 6, e109 (2014).

24) S. Peng, X. Yang, D. Tian, W. Deng ; ACS Appl. Mater. Interfaces, 6 , 15188 (2014).

25) P. Mazumder, Y. Jiang, D. Baker, A. Carrilero, D. Tulli, D. Infante, A. T. Hunt, V. Pruneri ; Nano Lett., 14, 4677 (2014).

26) J. Y. Lee, S. Pechook, B. Pokroy, J. S. Yeo ; Langmuir, 30, 15568 (2014)

27) T. L. Liu, C. J. Kim ; Science, 346, 1096 (2014).

28) Y. Wang, B. Bhushan; ACS Appl. Matter. Interfaces, 7, 743 (2015)

29) T. Li, M. Paliy, X. Wang, B. Kobe, W.-M. Lau, J. Yang ; ACS Appl. Mater. Interfaces, 7, 10988 (2015).

30) P. S. Brown, B. Bhushan ; Sci. Rep., 6, 21048 (2016).

31) B. Li, J. Zhang; Chem. Commun., 52, 2744 (2016).

32) A. Hozumi, D. F. Cheng, M. Yagihashi ; J. Colloid Interf. Sci., 353, $582(2011)$

33）J. N. Israelachvili ; 分子間力と表面力 第2版, 近藤保／大島広行訳, p.312 (浅倉書店, 1996).

34）赤松佳則 ; 表面技術, 60, 32 (2009).

35) K. Kawasaki ; J. Colloid Sci., 15, 402 (1960).

36) C. G. L. Furmidge ; J. Colloid Sci., 17, 309 (1962).

37) D. F. Cheng, C. Urata, B. Masheder, A. Hozumi ; J. Am. Chem. Soc., 134, 10191 (2012)

38) T-S. Wong, T. Sun, L. Feng, J. Aizenberg ; MRS Bull., 38, 366 (2013).

39) T. Wong, S. H. Kang, S. K. Y. Tang, E. J. Smythe, B. D. Hatton, A. Grinthal, J. Aizenberg ; Nature, 477, 443 (2011).

40) W. Ma, Y. Higaki, H. Otsuka, A. Takahara ; Chem. Commun., 49, 597 (2013) 
41) K. Manabe, S. Nishizawa, K.-H. Kyung, S. Shiratori ; ACS Appl. Mater. Interfaces, 6, 13985 (2014).

42) J. Zhang, L. Wu, B. Li, L. Li, S. Seeger, A. Wang ; Langmuir, 30, 14292 (2014).

43) D. F. Miranda, C. Urata, B. Masheder, G. J. Dunderdale, M. Yagihashi, A. Hozumi ; APL Mater, 2, 056108 (2014).

44) Y. Wang, H. Zhang, X. Liu, Z. Zhou ; J. Mater. Chem. A, 4, 2524 (2016).

45) H. Liu, P. Zhang, M. Liu, S. Wang, L. Jiang ; Adv. Mater., 25, 4477 (2013).

46) Y. Ding, J. Zhang, X. Zhang, Y. Zhou, S. Wang, H. Liu, L. Jiang ; $A d v$. Mater. Interfaces, 2, 1500177 (2015).

47) C. Urata, G. J. Dunderdale, M. W. England, A. Hozumi ; J. Mater. Chem. A., 3, 12626 (2015).

48) W. Chen, A. Y. Fadeev, M. C. Hsieh, D. Oner, J. Youngblood, T. J. McCarthy ; Langmuir, 15, 3395 (1999).

49) A. Y. Fadeev, T. J. McCarthy ; Langmuir, 15, 3759 (1999).

50) A. Y. Fadeev, T. J. McCarthy ; Langmuir, 15, 7238 (1999).

51) A. Hozumi, T. J. McCarthy ; Langmuir, 26, 2567 (2010).

52) D. F. Cheng, C. Urata, M. Yagihashi, A. Hozumi ; Angew. Chem. Int. Ed., 51, 2956 (2012).
53) C. Urata, D. F. Cheng, B. Masheder, A. Hozumi ; RSC Adv., 2, 9805 (2012).

54) C. Urata, B. Masheder, D. F. Cheng, A. Hozumi ; Langmuir, 28, 17681 (2012).

55) C. Urata, B. Masheder, D. F. Cheng, A. Hozumi ; Langmuir, 29, 12472 (2013).

56) C. Urata, B. Masheder, D. F. Cheng, A. Hozumi ; Chem. Commun.,49, 3318 (2013).

57) J. Park, C. Urata, B. Masheder, D. F. Cheng, A. Hozumi ; Green Chem., 15, 100 (2013).

58) B. Masheder, C. Urata, D. F. Cheng, A. Hozumi ; ACS Appl. Mater. Interfaces, 5, 154 (2013).

59) B. Masheder, C. Urata, A. Hozumi ; ACS Appl. Mater. Interfaces, 5 , 7899 (2013).

60) C. Urata, B. Masheder, D. F. Cheng, D. F. Miranda, G. J. Dunderdale, T. Miyamae, A. Hozumi ; Langmuir, 30, 4049 (2014).

61) J. W. Krumpfer, T. J. McCarthy ; Langmuir, 27, 11514 (2011).

62) L. Wang, T. J. McCarthy ; Angew. Chem. Int. Ed., 55, 244 (2016).

63) Y. Zushi, J. N. Hogarh, S. Masunaga ; Clean Technol. Environ. Policy, 14, 9 (2012).

64) A. B. Lindstrom, M. J. Strynar, E. L. Libelo ; Environ. Sci. Technol., 45, 7954 (2011). 